\title{
SINONIMI BAHASA KABOLA DAN BAHASA HAMAP \\ DI PULAU ALOR, NUSA TENGGARA TIMUR: SUATU KAJIAN DESKRIPTIF ANALISIS
}

\author{
Ida Ayu Iran Adhiti \\ IKIP PGRI Bali \\ dayuiran@gmail.com
}

\begin{abstract}
ABSTRAK
Kajian tentang pendataan bahasa-bahasa daerah di Pulau Alor dibutuhkan secara mendalam. Upaya pemerintah daerah untuk membina dan mengembangkan bahasa daerah telah dilaksanakan sebagai upaya untuk melestarikan bahasa daerah. Penelitian tentang fenomena bahasa daerah di Pulau Alor dilakukan oleh para pakar bahasa. Kajian ini menyangkut tentang Sinonimi bahasa Kabola dan bahasa Hamap di Pulau Alor. Pendataan kedua bahasa tersebut dianalisis dengan teori relasi makna. Pengumpulan data dikumpulkan dengan metode simak dan metode cakap yakni dengan menyimak pembicaraan informan dan mengajak bercakap-cakap. Metode pengumpulan data tersebut dibantu dengan metode wawancara. Metode ini bertujuan untuk menggali data secara optimal tentang beberapa hal secara mendalam. Berdasarkan hasil analisis, kosakata Bahasa Kabola dan bahasa Hamap ditemukan memiliki fenomena sinonimi. Kosakata yang memiliki kesamaan dan kemiripan bentuk tersebut dapat dikelompokkan menjadi: (1) sinonimi dengan penghilangan dan penambahan fonem vokal dan fonem konsonan pada posisi depan dan belakang kata; (2) sinonimi dengan pertalian fonem vokal dan konsonan pada posisi tengah kata dan belakang kata; (3) sinonimi dengan pertalian, penambahan, dan penghilangan suku kata pada suku kata pertama dan kedua; dan (4) sinonimi dengan bentuk atau berian mutlak sama.
\end{abstract}

Kata kunci: bahasa Kabola; relasi makna; sinonimi

\begin{abstract}
The study of local languages in Alor Island is needed in-depth. Local government efforts to foster and develop local languages have been made as an effort to preserve local languages. The research on the phenomenon of local languages in Alor Island is carried out by language experts. The study is discussed about Sinonimi and Hamap languages in Alor Island. The data collection of these two languages are analyzed with the theory of meaning relation. The data collection is compiled by listening and conversational methods, namely by listening to informant talks and inviting conversation. The data collection method is assisted with the interview method. This method id aimed to explore data optimally about several things in depth. Based on the analysis result, the vocabulary of Kabola and Hamap languages were found synonymy phenomenon. Vocabularies that have similarities and resemblance of these forms can be grouped into (1) synonymy by the removal and addition of vowel and consonant phonemes at the front and back positions of words; (2) synonymy with the relation of vowel and consonant phonemes in the middle and back positions of words; (3) synonymy with the relationship, addition, and omission of syllables in the first and second syllables; and (4) synonymy with the same absolute form or Iberian.
\end{abstract}

Keywords: Kabola language; meaning relation; synonimi

\section{PENDAHULUAN}

Fungsi bahasa secara umum sesungguhnya adalah sebagai alat komunikasi. Dalam kaitannya dengan masyarakat dalam dunia pendidikanpada prinsipnya fungsi bahasa dapat dibagi menjadi empat bagianyakni: fungsi kebudayaan, fungsi kemasyarakatan, fungsi 
perorangan, dan fungsi pendidikan. Di samping sebagai alat komunikasi, bahasa juga berfungsi untuk mempresentasikan maksud dan tujuan dari hasil pemikiran atau fakta yang akan diuraikan baik lisan maupun tertulis (Yusanti \& Dkk, 2019: 334). Bahasa-bahasa daerah di Nusa Tenggara Timur merupakan penanda identitas yang menjadi ciri pembeda dengan etnik yang lain serta menjadi bahasa pemersatu masyarakat penuturnya (Suryati, 2012: 197). Masyarakat memiliki pola-pola kebudayaan yang dikembangkan melalui pendidikan serta perorangan merupakan anggota masyarakat, sehingga fungsi bahasa tersebut saling berkaitan. Makna bahasa diungkapkan dengan unsur-unsur kebudayaan yang dapat dimodifikasi, dibatasi, dan diwarnai oleh kebudayaan yang menjadi wadahnya. Selanjutnya, makna bahasa juga dipengaruhi oleh keadaan atau "konteks situsi". Setiap factor keadaan berbahasa dapat mengubah makna unsur berbahasa (Nababan, 1986: 66 67).

Chaer mengatakan bahwa bahasa merupakan sistem lambang bunyi berbentuk ujaran sehingga memiliki makna (Chaer, 2014: 44-45). Dengan kata lain bahwa bahasa dikatakan memiliki makna apabila memiliki lambang bunyi yang memiliki pengertian. Lambang bunyi tersebut menyangkut konsep, ide, dan pikiran yang disampaikan dalam bentuk wujud bunyi tertentu. Di samping itu bahasa juga dikatakan bersifat arbitrer, dengan maksud bahwa bahasa itu bersifat manasuka atau sewenang-wenang. Setiap bahasa tidak memiliki hubungan antara lambang bahasa tersebut dengan konsep yang ada di dalamnya.

Pemertahanan suatu bahasa berarti masyarakat melestarikan guyub bahasanya. Masyarakat menggunakan bahasanya sebagai wujud monolingual (ekabahasawan) dan tidak menghendaki penggunaan bahasa lain. Mereka mempertahan pola bahasa yang dimiliki sebagai wujud kecintaan terhadap bahasanya. Apabila ditemukan imigran di suatu wilayah yang bertujuan mempengaruhi bahasa mereka maka akan ditemukan masyarakat yang berusaha mempertahankan bahasanya. Pada kenyataannya banyak pula terjadi pemertahanan bahasa berkaitan dengan penduduk yang menetap, bukan karena imigran (Sumarsono, 2010).
Linguistik adalah ilmu yang mempelajari tentang bahasa, atau ilmu yang mengkaji tentang seluk beluk bahasa secara menyeluruh. Secara harafiah berarti bahwa bahasa yang dipelajari adalah bahasa tutur sehari-hari dan sebagai objek sasaran yang dikhususkan. Dalam menghadapi objeknya, linguistik juga mempunyai "dugaan-dugaan mula" akibat dari pengamatan dan pertanyaan-pertanyaan terhadap gejala-gejala tertentu (fonem-fonem) yang tampak menonjol pada pengamatan bahasa tertentu (Sudaryanto, 1986: 24).

Kesemestaan bahasa terjadi pada semua bahasa dan budaya, hanya prinsip-prinsip umum masih tetap berlaku. Keragaman tersebut berfungsi menentukan konsep bahasa dalam aspek lain dari prilaku manusia. Konsep bahasa mengkhususkan pada perilaku linguistik, aplikasinya terkait dengan wilayah semantik yang terorganisir (Greenberg, 1963: 61).

Pendataan tentang bahasa-bahasa daerah di Pulau Alor, Nusa Tenggara Timur perlu dilakukan. Penelitian tentang fenomena kebahasaan telah banyak dilakukan oleh pakar linguistik di Indonesia maupun dari mancanegara.. Bahasa-bahasa daerah di Pulau Alor memiliki keunikan tersendiri, apabila dikaji secara mendalam fenomena kebahasaannya. Jenis dan junlah bahasanya cukup banyak dengan karakter yang berbedabeda. Masyarakat setempat membina, memelihara, dan melestarikan bahasa daerah masing-masing. Setiap daerah memiliki bahasa tersendiri, yang digunakan sebagai alat komunikasi antar etnis dalam kehidupan sehari-hari. Bahasa daerah yang mereka miliki biasanya digunakan untuk komunikasi pada acara ibadah pada upacara keagamaan tertentu. Perbedaan bahasa yang menyolok ditemukan pada beberapa daerah, walaupun memiliki jarak cukup dekat dengan pendukung bahasa yang bersangkutan. Sebaliknya ditemukan pula beberapa bahasa yang memiliki persamaan atau kemiripan terhadap fenomena kebahasaannya walaupun memiliki jarak yang cukup jauh, jika dibandingkan dengan bahasa daerah lainnya.

Kabupaten Alor memiliki 18 (delapan belas) bahasa daerah yang masih hidup, dilestarikan dan dikembangkan oleh masyarakat setempat. Bahasa-bahasa daerah tersebut antara lain: (1) Bahasa Daerah Alores; 
(2) Bahasa Daerah Kabola/Adang; (3) Bahasa Daerah Abui/A'fui; (4) Bahasa Daerah Hamap; (5) Bahasa Daerah Klon; (6) Bahasa Daerah Kui; (7) Bahasa Daerah Kafoa; (8) Bahasa Daerah Panea; (9) Bahasa Daerah Kamang; (10) Bahasa Daerah Kailesa; (11) Bahasa Daerah Wersin/Kula; (12) Bahasa Daerah Talangpui/Sawila; (13) Bahasa Daerah Blagar/Pura; (14) Bahasa Daerah Retta; (15) Bahasa Daerah Taiwa; (16) Bahasa Daerah Nedebang/Bintang/Kalamu; (17) Bahasa Daerah Deing/Diang; dan (18) Bahasa Daerah Lamma.

Kedelapan belas bahasa-bahasa daerah tersebut dikelompokkan berdasarkan klasifikasi, daerah penyebaran dan luas daerah pemakainya yakni bahasa daerah terbesar, menengah, dan terkecil (Retika.E.Thobyn., 2012).

Setiap penelitian menggunakan teori yang memiliki peranan penting untuk mengkaji, menganalisis, serta mendeskripsikan masalah yang diteliti. Di samping itu teori juga berperan untuk memfokuskan suatu masalah serta metode-metode yang digunakan dalam penelitian bahasa (Kridalaksana, 1984: 193); (Sarwono, 2006: 197)).

Sesungguhnya unsur-unsur bahasa yang memiliki pertautan pada bahasa itu sendiri disebut makna. Di samping itu hal yang dapat dipahani dan dimengerti serta disepakati oleh para pemakai bahasa atau pendukungnya disebut makna. Ilmu yang mempelajari tentang makna disebut semantik, istilah ini digunakan oleh para pakar bahasa yang mempelajari tentang makna.

Makna dapat diuraikan atas unsur-unsur utamanya. Ditinjau dari pendekatan secara analitik atau refrensial makna bertujuan mencari esensinya. Sedangkan pendekatan secara operasional makna mempelajari kata dalam penggunaannya (Djajasudarma, 2009: 7). Di samping itu makna berfungsi untuk menjelaskan dan mendeskripsikan makna secara alamiah serta menjelaskan makna secara komunikasi (Pateda, 2001: 79): (Goddard, 1996: 2)). Selanjutnya, makna memiliki seperangkat fitur makna, memiliki ciri makna umum yang sama serta berada pada tataran komunikasi sosial dengan faktor kontekstual (Nida, 1975: 174); (Ullmann, 1985).
Kajian tentang makna dan relasi makna terkait dengan kajian sinonimi, antonimi, polisemi, homonimi, hiponimi, ambiguiti, dan redundansi. Relasi makna merupakan hubungan semantik yang terdapat antara satuan bahasa yang satu dengan satuan bahasa yang lain. Satuan bahasa tersebut dapat berupa kata, frase, maupun kalimat. Relasi makna dapat menyatakan kesamaan makna, pertentangan makna, ketercakupan makna, kegandaan makna, atau kelebihan makna (Chaer, 2014; 297).

Menurut Chaer mengungkapkan bahwa sinonimi adalah kata (leksem) yang berbeda tetapi memiliki arti yang sama (Chaer, 1986: 149). Dengan kata lain leksem mengacu pada satu unit semantik yang sama. Dapat dikatakan, bahwa kata-kata yang memiliki relasi makna yang sama disebut sinonimi. Dengan demikian sinonimi merupakan bentuk bahasa yang memiliki makna mirip atau sama. Sinonimi dapat berupa kata, kelompok kata atau kalimat (Kridalaksana, 1984: 179). Dalam bahasa Indonesia Indonesia digunakan untuk menyatakan kesamaan arti dalam bentuk : pronomina persona seperti: aku, hamba, kami, beta; kata-kata dengan nilai rasa berbeda seperti: sedekah, anugerah, karunia, persembahan, amal; kondisi sesuatu yang memiliki kemiripan makna seperti: rumah, istana; dan suatu hubungan seperti: anak dan putera, kaki tangan dan pembantu, buruh dan karyawan, penyair dan pujangga (Djajasudarma, 2009: 55).

Penelitian terhadap bahasa Kabola dan bahasa Hamap pada kajian relasi makna dipaparkan tentang gejala sinonimi berupa sejumlah kosakata yang ditemukan pada kedua bahasa tersebut.

\section{METODE}

Penelitian tentang sinonimi bahasa Kabola dan bahasa Hamap di Pulau Alor bertujuan untuk mendeskripsikan, menguraikan, dan menjelaskan bentuk kosakata yang bersinonim serta pengelompokan kosakatanya. Keberbedaan bahasa-bahasa daaerah di tempat penelitian tidak membatasi masyarakat dalam berkomunikasi terutama pada kegiatan upacara adat. Masyarakat masing-masing suku tetap bertahan menggunakan bahasa daerahnya sendiri. Kajian tentang sinonimi terhadap 
bahasa Kabola dan bahasa Hamap bersifat deskriptif analisis, dengan maksud untuk dapat mendeskipsikan, menguraikan, dan mengkaji fenomena kebahasannya pada satu kurun waktu.

Lokasi penelitian bahasa Kabola dilakukan di Desa Lendola, Teluk Mutiara, Kecamatan Alor Barat Laut. Sedang penelitian tentang bahasa Hamap dilakukan di Desa Moru, Kecamatan Alor Barat Daya.

Bahasa-bahasa lain menyebar di beberapa desa misalnya: bahasa Alores, bahasa Abui, bahasa Kui, bahasa Kafoa, bahasa Panea, bahasa Kamang, bahasa Kailesa, bahasa Wersin, bahasa Tanglapui, bahasa Blagar, bahasa Retta, bahasa Taiwa, bahasa Nedebang, bahasa Deing, dan bahasa Lamma.

Ayatrohaedi mengatakan bahwa beberapa metode dapat digunakan untuk menggali data di daerah penelitian (Ayatrohaedi, 1979: 33). Metode tersebut dapat dijabarkan menjadi metode simak dan metode cakap (band.dengan (Sudaryanto, 1986: 2-9); (Mahsun, 2013: 9296)). Menurut Bungin metode ini disebut sebagai metode observasi (Bungin, 2008).

Dengan demikian metode observasi digunakan untuk melakukan pengamatan di lokasi penelitian, sehingga memperoleh gambaran secara utuh dan menyeluruh tentang data kebahasaan yang sedang diamati (Muhadjir, 1998: 180). Metode wawancara dilakukan dengan tanya jawab kepada informan untuk memperoleh data secara mendalam (Danandjaya, 1994: 102).

Pada penelitian ini, data digali bersumber dari informan sebagai data primer atau data utama. Informan kunci digunakan sebagai informan utama, dibantu oleh 2 (dua) orang informan lain untuk membantu dan mendukung data yang digali.. Dengan demikiann jumlah informan yang diwawancarai pada daerah penelitian masing-masing bahasa sebanyak 3 orang. Data sekunder digunakan dalam penelitian, berfungsi untuk membantu data primer dengan mengacu sejumlah sumbern buku yang membahas tentang fenomena bahasa yang diteliti oleh beberapa pakar. Apabila ditemukan data yang tidak akurat dari informan maka dilakukan pengecekan ulang terhadap informan lain agar data yang diperoleh menjadi valid. Penjaringan data dilakukan dengan menggunakan 1.500 kosakata daftar Holle yang memuat tentang konstruksi kata tertentu. Daftar pertanyaan yang telah tersusun dibantu dengan cerita tentang keberadaan bahasa yang diteliti. Penjaringan data dibantu dengan teknik perekaman dengan tape recorder, serta camera digital untuk mendokumentasikan data yang digali. Data nonkebahasaan juga digali berdasarkan cerita rakyat atau dongeng dari informan kunci yang memahami tentang budaya dan adat di daerah penelitian. Data yang digali berfungsi untuk mendeskripsikan, menguraikan, serta menganalisis secara umum bahasa yang dikaji secara kualitatif.

Data dianalisis dengan kajian deskriptif analisis yakni mendeskripsikan, menguraikan, dan dianalisis berdasarkan satu kurun waktu. Analisis dibantu dengan metode perbandingan yakni membandingkan kedua bahasa yang dikaji sehingga memperoleh kajian yang sesuai dengan anaisis. Tahapan penganalisisan data, peneliti menggunakan metode deskriptif analisis, yakni mendeskripsikan bahasa-bahasa di daerah penelitian. Teknik lanjutannya adalah teknik hubung banding, baik hubung banding membedakan maupun menyamakan kedua bahasa yang dikaji (Sudaryanto, 1986: 13-30); (Djajasudarma, 1993: 158); dan (Mahsun, 2013)).

Analisis data disajikan dengan metode formal yakni menggunakan tanda dan lambang linguistik untuk penulisan secara fonemis seperti: /.../ dan fonem konsonan 'ng' ditulis /n/. Metode formal pada kajian ini dibantu dengan metode informal, yakni menyajikan dalam bentuk uraian atau kata-kata yang menganalisis secara kualitatif data yang dikaji. (Sudaryanto, 1986: 45).

\section{PEMBAHASAN}

Klasifikasi bahasa-bahasa daerah di Pulau Alor berdasarkan daerah penyebaran dan luas daerah pemakainya dapat dikelompokkan menjadi: 1) bahasa terbesar, 2) bahasa menengah, dan 3) bahasa terkecil.

Klasifikasi bahasa-bahasa tersebut adalah sebagai berikut.

1) Terbesar adalah bahasa Abui, bahasa Kabola/Adang, bahasa Alores/ Alurung, bahasaTanglapui/ Sawila, bahasa Blagar/ Pura, bahasa Klon, dan Bahasa kailesa

2) Menengah adalah bahasa Kui, bahasa Kamang, bahasa Wersin/Wersina, 
bahasaTaiwa, bahasa Lamma, bahasaDiang/Deing, bahasa Hamap, dan bahasa Kafoa.

3) Terkecil adalah bahasa Panea, bahasa Retta, dan bahasa Nedebang/ Bitang/ Kalamu.

Berdasarkan klasifikasi dan luas daerah pemakaiannya dapat dikatakan bahwa bahasabahasa yang menjadi kajian penelitian ini yakni bahasa Kabola dan bahasa Hamap, tergolong bahasa terbesar dan menengah.

Karakteristik kedua bahasa tersebut dapat dipaparkan sebagai berikut.

1) Bahasa Kabola

Menurut peneliti bahasa-bahasa daerah di Pulau Alor, Retika (2012:8) bahwa bahasa Kabola juga disebut bahasa Adang. Bahasa Kabola sebagian besar terdapat di wilayah Kepala Adang Burung (ABAL). Berdasarkan kedudukan dan fungsinya, bahasa Kabola memiliki kedudukan dan fungsi yang cukup penting. Bahasa Kabola digunakan sebagai alat komunikasi pada kehidupan sehari-hari oleh masyarakat setempat. Kenyataan ini terlihat saat masyarakat berkomunikasi di tempat umum seperti di pasar tradisional maupun tempat lainnya bagi masyarakat antar etnisnya. Penggunaan bahasa tersebut lebih tinggi prosentase penggunaannya di tempat ibadah seperti di mesjid maupun di gereja. Penggunaan bahasa daerah tertinggi digunakan oleh masyarakat saat kegiatan upacara adat atau upacara keagamaan seperti: upacara pernikahan, upacara meninggal, upacara bayi baru lahir, maupun upacara lain.

Berdasarkan hasil pengamatan dapat dikatakan bahwa penggunaan bahasa Kabola di pasar tradisional sekitar $80 \%$, sedangkan penggunaan bahasa daerah di tempat umum seperti super market atau pertokoan ditemukan penggunaannya sekitar sekitar $20 \%$. Masyarakat setempat menganggap, bahwa bahasa Kabola merupakan bahasa yang paling santun, seperti kata hemap berati 'kesana' serta hepop berarti 'kesini'. Pada bahasa Hamap he pomi berarti 'kesana' serta mounghewi berarti 'kesini'.

2) Bahasa Hamap
Retika (2012:8) mengatakan bahwa bahasa daerah Hamap ditemukan di sekitar Moru sampai daerah Wolwa. Sejumlah kosakata bahasa Hamap memiliki kesamaan dan kemiripan dengan bahasa Kabola. Kosakata kedua bahasa tersebut memiliki bentuk yang sama atau mirip tetapi memiliki makna atau arti yang sama. Bahasa Hamap memiliki ciri yang hampir sama dengan bahasa Kabola. Fungsi dan kedudukan bahasa tersebut cukup penting di masyarakat. Terutama pada kegiatan upacara adat seprti: upacara pernikahan, upacara meninggal, upacara bayi baru lahir maupun upacara lain. Ditinjau dari prosentase penggunaannya, di pasar tradisional digunakan sekitar $80 \%$ sedangkan di tempat umum seperti pertokoan atau perkantoran digunakan sekitar $20 \%$. Bahasa Hamap pada dasarnya digunakan antar etnis bagi masyarakat setempat. Generasi muda tidak banyak mampu untuik menggunakan bahasa daerahnya karena dalam berkomunikasi sehari-hari menggunakan bahasa Indonesia.

Data berikut menggambarkan kesamaan dan kemiripan kosakata bahasa Kabola dan bahasa Hamap di Pulau Alor.

Tabel 1. Kemiripan Kosakata Bahasa Kabola dan Bahasa Hamap di Pulau Alor

\begin{tabular}{|c|c|c|c|}
\hline No & $\begin{array}{l}\text { Bahasa } \\
\text { Kabola }\end{array}$ & $\begin{array}{l}\text { Bahasa } \\
\text { Hamap }\end{array}$ & Glos \\
\hline 1 & lnabal & Inab/ & 'apa' \\
\hline 2 & /hiu/ & /hif/ & 'ayam' \\
\hline 3 & /taral & /taru/ & 'berbaring' \\
\hline 4 & /ib'an/ & /ib'in/ & 'bintang' \\
\hline 5 & /toromi/ & $/$ to' $^{\prime} \mathrm{mi} /$ & 'di mana' \\
\hline 6 & /mihi/ & $/ \mathrm{mih} /$ & 'duduk' \\
\hline 7 & lut/ & $\mid u^{\prime} t /$ & 'empat' \\
\hline 8 & /bo'oi/ & /ba'oir/ & 'kuning' \\
\hline 9 & /koin/ & loin/ & 'kutu' \\
\hline 10 & /batan/ & /batiq/ & 'jarum' \\
\hline 11 & /letel & /let/ & 'jauh' \\
\hline 12 & /denwel & /denfel & 'kapan' \\
\hline 13 & /ka'ai/ & /ka'ain/ & 'kecil' \\
\hline 14 & /ta'atul & /ta'at/ & 'kering' \\
\hline 15 & /bulun' & /bulan/ & 'langit' \\
\hline 17 & /kopuin/ & /o'puin/ & 'memegang' \\
\hline 18 & /tar'rai/ & /tar'ral & 'memilih' \\
\hline
\end{tabular}




\begin{tabular}{|c|c|c|c|}
\hline 19 & /ta'aul & /ta'aul & 'mencuri' \\
\hline 20 & /masan/ & /masan/ & 'menembak' \\
\hline 21 & /kehel & lehel & 'menggigit' \\
\hline 22 & /pocol & /poot/ & 'mengikat' \\
\hline 23 & /dumu/ & /duit/ & 'mengisap' \\
\hline 24 & lte'el & /te/ & 'menikam' \\
\hline 25 & /haroto/ & /arotol & 'menjahit' \\
\hline 26 & lnal & Inal & 'minum' \\
\hline 27 & /tatu/ & $\mid t a /$ & 'mulut' \\
\hline 28 & /han' & /pahan' & 'mengunyah' \\
\hline 29 & /tuwu/ & $/ t u /$ & 'menggaruk' \\
\hline 30 & /to'on/ & Ito'an' & 'pendek' \\
\hline 31 & /buni/ & /bunel & 'panas' \\
\hline 32 & Inu/ & $/ \mathrm{lnu} /$ & 'satu' \\
\hline 33 & /narin/ & /nerin/ & 'saya' \\
\hline 34 & /nimi/ & /nime/ & 'orang' \\
\hline 35 & /kupuhu/ & /kupuh/ & 'sempit' \\
\hline
\end{tabular}

Gejala sinonimi pada data di atas menunjukkan sinonimi dalam bentuk kosakata pada bahasa Kabola dan bahasa Hamap. Sinonimi tersebut berupa pertalian fonem vokal dan konsonan, penambahan dan penghilangan fonem vokal dan konsonan, penambahan dan penghilangan suku kata, serta sinonimi multak yang terdapat pada kedua kosakata tersebut.

Keseluruhan gejala sinonimi kosakata data di atas dapat dikelompokkan sebagai berikut

Tabel 2. Data 1

\begin{tabular}{llll}
\hline No & $\begin{array}{l}\text { Bahasa } \\
\text { Kabola }\end{array}$ & $\begin{array}{c}\text { Bahasa } \\
\text { Hamap }\end{array}$ & \multicolumn{1}{c}{ Glos } \\
\hline $\mathrm{a}$ & /naba/ & /nab/ & 'apa' \\
\hline $\mathrm{b}$ & /koin/ & /oin/ & 'kutu' \\
\hline $\mathrm{c}$ & /lete/ & /let/ & 'jauh' \\
\hline $\mathrm{d}$ & /bo'oi/ & /bo'oir/ & 'kuning' \\
\hline $\mathrm{e}$ & /kehe/ & /ehe/ & 'menggigit' \\
\hline $\mathrm{f}$ & $/$ /ka'ai/ & /ka'ain/ & 'kecil' \\
\hline $\mathrm{g}$ & /ta'atu/ & /ta'at/ & 'kering' \\
\hline $\mathrm{h}$ & /kopuin/ & /o'puin/ & 'memegang' \\
\hline $\mathrm{i}$ & /tar'rai/ & /tar'ra/ & 'memilih' \\
\hline $\mathrm{j}$ & /te'e/ & /te/ & 'menikam' \\
\hline $\mathrm{k}$ & /haroto/ & /aroto/ & 'menjahit' \\
\hline
\end{tabular}

Data 1. a Kosakata /naba/ 'apa' pada bahasa Kabola ditemukan kata /nab/'apa' pada bahasa Hamap, berarti terjadi penghilangan fonem vokal/a/ pada bahasa Hamap pada posisi belakang.

Data 1.b Kosakata /koin/'kutu' pada bahasa Kabola ditemukan kata /oin/'kutu' pada bahasa
Hamap, terjadi penghilangan fonemvokal / $/ \mathbf{k}$ pada bahasa Hamap pada posisi depan. Data 1.c Kosakata /lete/'jauh' pada bahasa Kabola ditemukan kata /let/'jauh' pada bahasa Hamap, terjadi penghilangan fonem vokal / e/ pada bahasa Hamap pada posisi belakang.

Data 1.d Kosakata /bo'oi/'kuning' pada bahasa Kabola ditemukan kata /bo'oir/'kuning' pada bahasa Hamap, terjadi penambahan fonem konsonan $|r|$ pada bahasa Hamap pada posisi belakang.

Data 1.e Kosakata /kehe/'menggigit' pada bahasa Kabola ditemukan kata lehe/'menggigit' pada bahasaHamap, terjadi penghilangan fonem konsonan $/ \boldsymbol{k} /$ pada bahasa Hamap pada posisi belakang.

Data 1.f Kosakata /ka'ai/'kecil' pada bahasa Kabola ditemukan kata /ka'ain/'kecil' pada bahasa Hamap, terjadi penambahan fonem konsonan $/ \boldsymbol{\eta} /$ pada bahasa Hamap pada posisi belakang.

Data 1.g Kosakata /ta'atu/'kering' pada bahasa Kabola ditemukan kata /ta'at/'kering' pada bahasa Hamap, terjadi penghilangan fonemvokal /u/ pada bahasa Hamap pada posisi belakang.

Data 1.h Kosakata /ko'puin/'memegang' pada bahasa Kabola ditemukan kata /o,puin/'memegang' pada bahasa Hamap, terjadi penghilangan fonem konsonan $/ \boldsymbol{k} /$ pada bahasa Hamap pada posisidepan.

Data 1.i Kosakata /tar 'rai/'memilih' pada bahasa Kabola ditemukan kata Itar'ra/'memilih' pada bahasa Hamap, terjadi penghilangan fonem vokal /i/ pada bahasa Hamap pada posisi belakang.

Data 1.j Kosakata Ite'e/'menikam'pada bahasa Kabola ditemukan kata /te/'menikam' pada bahasa Hamap, terjadi penghilangan fonem vokal /e/ pada bahasa Hamap pada posisi belakang.

Data 1.k Kosakata /haroto/'menjahit'pada bahasa Kabola ditemukan kata /aroto/'menjahit'pada bahasa Hamap, terjadi penghilangan fonem konsonan $/ \boldsymbol{h} /$ pada bahasa Hamap pada posisi depan.

Tabel 3. Data 2

\begin{tabular}{llll}
\hline No & $\begin{array}{l}\text { Bahasa } \\
\text { Kabola }\end{array}$ & $\begin{array}{l}\text { Bahasa } \\
\text { Hamap }\end{array}$ & \multicolumn{1}{c}{ Glos } \\
\hline a & /hiu/ & /hif/ & 'ayam' \\
\hline b & /tara/ & /taru/ & 'berbaring' \\
\hline
\end{tabular}




\begin{tabular}{|c|c|c|c|}
\hline $\mathrm{c}$ & /nimi/ & /nimel & 'orang' \\
\hline d & /buni/ & /bune/ & 'panas' \\
\hline $\mathrm{e}$ & /batan! & /batin/ & 'jarum' \\
\hline f & /denwel & ldenfel & 'kapan' \\
\hline $\mathrm{g}$ & /bulun/ & /bulan! & 'langit' \\
\hline $\mathrm{h}$ & /to'on/ & Ito'an/ & 'pendek' \\
\hline $\mathrm{i}$ & /narin/ & /nerin/ & 'saya' \\
\hline $\mathrm{j}$ & /to'on! & /to'an! & 'pendek' \\
\hline
\end{tabular}

Data 2a Kosakata /hiu/'ayam'pada bahasa Kabola ditemukan kata /hif/'ayam'pada bahasa Hamap, terjadi pertalian fonemvokal/u/dengan fonem konsonan /f// pada bahasa Kabola dan bahasa Hamap pada posisi belakang.

Data 2 b Kosakata/tara/'berbaring'pada bahasa Kabola ditemukan kata Itaru/'berbaring'pada bahasa Hamap, terjadi pertalian fonem vocal /a/ dengan fonem vokal /u/l pada bahasa Kabola dan bahasa Hamap pada posisi belakang.

Data 2.cKosakata /bata $/$ 'jarum'pada bahasa Kabola ditemukan kata Ibatin/'jarum'pada bahasa Hamap, terjadi pertalian fonem vocal /a/ dengan fonem vokal /i/ pada bahasa Kabola dan bahasa Hamap pada posisi tengah.

Data 2.d Kosakata /denwe/'kapan'pada bahasa Kabola ditemukan kata Idenfe/'kapan'pada bahasa Hamap, terjadi pertalian fonem konsonan/w/ dengan fonem vokal /f/ pada bahasa Kabola dan bahasaHamap pada posisi tengah.

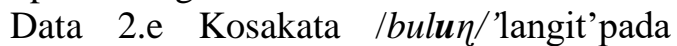
bahasa Kabola ditemukan kata Ibulan/'langit'pada bahasa Hamap, terjadi pertalian fonem vokal /u/ dengan fonem vokal /a/ pada bahasa Kabola dan bahasa Hamap pada posisi tengah.

Data 2.f Kosakata /nimi/'orang'pada bahasa Kabola ditemukan kata Inime/'orang'pada bahasa Hamap, terjadi pertalian fonem vokal /i/ dengan fonem vokal /e/ pada bahasa Kabola dan bahasa Hamap pada posisi akhir.

Data 2.g Kosakata /to'o $\eta$ /'pendek'pada bahasa Kabola ditemukan kata Itoan/'pendek'pada bahasa Hamap, terjadi pertalian fonem vokal /o/ dengan fonem vokal /a/ pada bahasa Kabola dan bahasa Hamap pada posisi tengah.

Data 2.h Kosakata /buni/'panas'pada bahasa Kabola ditemukan kata /bune/'panas'pada bahasa Hamap, terjadi pertalian fonem vokal $/ i /$ dengan fonem vokal /e/ pada bahasa Kabola dan bahasa Hamap pada posisi akhir.

Data 2.i Kosakata /narin/'saya'pada bahasa Kabola ditemukan kata /nerin/'panas'pada bahasa Hamap, terjadi pertalian fonem vokal/a/ dengan fonem vokal /i/ pada bahasa Kabola dan bahasa Hamap pada posisi tengah.

Data 2.j Kosakata /to'o $\eta /$ 'pendek'pada bahasa Kabola ditemukan kata Ito'an/'pendek'pada bahasa Hamap, terjadi pertalian fonem vokal /o/ dengan fonem vokal /a/ pada bahasa Kabola dan bahasa Hamap pada posisi tengah.

Tabel 4. Data 3

\begin{tabular}{|c|c|c|c|}
\hline No & $\begin{array}{l}\text { Bahasa } \\
\text { Kabola }\end{array}$ & $\begin{array}{l}\text { Bahasa } \\
\text { Hamap }\end{array}$ & Glos \\
\hline $\mathrm{a}$ & /ib'an' & lib’in/ & 'bintang' \\
\hline $\mathrm{b}$ & /poco/ & /poot/ & 'mengikat' \\
\hline $\mathrm{c}$ & /dumu/ & /duit/ & 'mengisap' \\
\hline $\mathrm{d}$ & /han/ & /pahan' & 'mengunyah' \\
\hline $\mathrm{e}$ & /tuwu/ & $\mid t u /$ & 'menggaruk' \\
\hline $\mathrm{f}$ & /toromi/ & /to'mi/ & 'di mana' \\
\hline $\mathrm{g}$ & Itatu/ & ltal & 'mulut' \\
\hline
\end{tabular}

Data 3.a Kosakata /ib'an/'bintang'pada bahasa Kabola ditemukan kata /ib'in/'bintang'pada bahasa Hamap, terjadi pertalian suku kata /an/ dengan suku kata /i $/$ pada bahasa Kabola dan bahasa Hamap pada suku kata kedua.

Data 3.b Kosakata /poco/'mengikat'pada bahasa Kabola ditemukan kata /poot/'mengikat'pada bahasa Hamap, terjadi pertalian suku kata /co /dengan suku kata /ot/ pada bahasa Kabola dan bahasa Hamap pada suku kata kedua.

Data 3.cKosakata/dumu/'mengisap'pada bahasa Kabola ditemukan kata /duit/'bintang'pada bahasa Hamap, terjadi pertalian suku kata /mu/ dengan suku kata /it/ pada bahasa Kabola dan bahasa Hamap pada suku kata kedua.

Data 3.d Kosakata /han/'mengunyah'pada bahasa Kabola ditemukan kata /pahan/'mengunyah'pada bahasa Hamap, terjadi penambahan suku kata/pa/ pada bahasa Hamap pada suku kata kedua.

Data 3.e Kosakata /tuwu/'menggaruk'pada bahasa Kabola ditemukan kata 
Itu/'menggaruk'pada bahasa Hamap, terjadi penghilangan suku kata /wu /pada bahasa Hamap di suku kata kedua.

Tabel 5. Data 4

\begin{tabular}{llll}
\hline No & $\begin{array}{l}\text { Bahasa } \\
\text { Kabola }\end{array}$ & $\begin{array}{l}\text { Bahasa } \\
\text { Hamap }\end{array}$ & \multicolumn{1}{c}{ Glos } \\
\hline $\mathrm{a}$ & $/ \mathrm{tt} /$ & $/ \mathrm{u}^{\prime} \mathrm{t} /$ & 'empat' \\
\hline $\mathrm{b}$ & $/ \mathrm{ta}{ }^{\prime} \mathrm{au} /$ & $/ \mathrm{ta}{ }^{\prime} \mathrm{au} /$ & 'mencuri' \\
\hline $\mathrm{c}$ & $/ \mathrm{masa \eta} /$ & $/ \mathrm{masa \eta} /$ & 'menembak' \\
\hline $\mathrm{d}$ & $/ \mathrm{na} /$ & $/ \mathrm{na} /$ & 'minum' \\
\hline $\mathrm{e}$ & $/ \mathrm{nu} /$ & $/ \mathrm{nu} /$ & 'satu' \\
\hline $\mathrm{f}$ & $/ \mathrm{ta}{ }^{\prime} \mathrm{au} /$ & $/ \mathrm{ta}{ }^{\prime a u} /$ & 'mencuri' \\
\hline
\end{tabular}

Data 4a, 4b, 4c, 4d, 4e, dan 4f yakni kosakata /utl 'empat',/ta'au/'mencuri', Imasan/'menembak', /na/'minum', dan Ita'au/'mencuri'pada bahasa Kabola memiliki berian atau bentuk kosakata yang sama pada bahasa Hamap. Hal ini menunjukkan adanya gejala sinonimi total yang sepenuhnya memiliki bentuk dan makna yang sama.

\section{SIMPULAN}

Berdasarkan kajian dan uraian analisis pada pembahasan di atas dapat disimpulkan beberapa hal sebagai berikut. Bahasa Kabola dan bahasa Hamap di Pulau Alor ditemukan kosakata yang bersinonim. Kosakata yang memiliki kesamaan dan kemiripan bentuk tersebut dapat dikelompokkan menjadi: (1) sinononimi dengan penghilangan dan penambahan fonem vokal dan fonem konsonan pada posisi depan dan belakang kata; (2) sinonimi dengan pertalian fonem vokal dan konsonan pada posisi tengah kata, dan belakang kata; (3) sinonimi dengan pertalian, penambahan, dan penghilangan suku kata pada suku kata pertama dan kedua; dan (4) sinonimi dengan bentuk atau berian mutlak sama.

\section{DAFTAR PUSTAKA}

Ayatrohaedi. (1979). Dialektologi: sebuah pengantar. Pusat Pembinaa dan Pengembangan Bahasa Departemen Pendidikan dan Kebudayaan.

Bungin. (2008). Penelitian kualitatif. Prenada Media Group.
Chaer, A. (1986). Linguistik Suatu Pengantar. Angkasa.

Chaer, A. (2014). Linguistik Umum. Rineka Cipta.

Danandjaya, J. (1994). Foklor Indonesia, ilmu gosip, dongeng dan lain-lain. PT Temrit.

Djajasudarma, T. F. (1993). Metode Linguistik: Ancangan Metode Penelitian dan Kajian. Eresco.

Djajasudarma, T. F. (2009). Semantik; Makna Leksikal dan Gramatikal. Refika Aditama.

Goddard, C. C. (1996). Grammatical categories and semantic primes. Australian National University.

Greenberg, J. H. (1963). Intoduction,Universals of language $X$. Mass.

Kridalaksana, H. (1984). KamusLinguistik. PT Gramedia.

Mahsun. (2013). Metode penelitian bahasa tahapan strategi, metode, dan tekniknya. Rajawali Pers.

Muhadjir, H. N. (1998). Metode Penelitian Kualitatif (111th ed.). Rake Sarasen.

Nababan, P. W. J. (1986). Sosiolinguistik. PT Gramedia.

Nida, E. A. (1975). Componential Analysis of Meaning: An Introduction to Semantic Structures. The Hague Mouton.

Pateda. (2001). SemantikLeksikal. PT Rineka Cipta.

Retika.E.Thobyn. (2012). Sejarah dan budaya kepulauan Alor. Nidya Pustaka.

Sarwono, J. (2006). Metode Penelitian Kuantitatif dan Kualitatif. Graha Ilmu.

Sudaryanto. (1986). Metode linguistik. Gadjah Mada University Press.

Sumarsono. (2010). Sosiolinguistik. Sabda (Lembaga Studi Agama, Budaya dan Perdamaian.

Suryati, N. M. (2012). Variasi fonologis dan leksikal bahasa Lio di Flores, Nusa Tenggara Timur: kajian dialek geografi. Universitas Udayana.

Ullmann, S. (1985). Pengantar sematik" (alih bahasa dan adaptasi oleh sumarsono). Fakultas Keguruan dan Ilmu Pendidikan Universitas Udayana.

Yusanti, I. P., \& Dkk. (2019). KesinonimanBerita Online dalam Situs KomisiPemberantasanKorupsi (KPK). Prosiding Seminar Nasional Linguistik 
SINONIMI BAHASA KABOLA DAN BAHASA HAMAP ...

Dan Sastra (SEMANTIKS). s/article/view/39030

https://jurnal.uns.ac.id/prosidingsemantik 